\title{
Diversification of water supply
}

\author{
Janusz $\operatorname{Rak}^{1}$, and Krzysztof Boryczko ${ }^{2, *}$ \\ ${ }^{1}$ Faculty of Civil and Environmental Engineering and Architecture, 35-959 Rzeszow, Poland
}

\begin{abstract}
The subject of the publication is the presentation of a methodology for determining the degree of diversification of water resources in collective water supply systems (= CWSS). Knowing the number of subsystems for water supply and their share of total water production, it is possible to calculate the dimensionless Pielou index. Similarly, the diversification indicators for networked water tanks (number and volume) and pressure pipelines of the second degree pumping station (number and flowability) can be determined. The work presents the calculation of diversification indices for selected CWSS in Poland. The presented methodology gives the possibility of three-parameter evaluation of settlement units with different water demand and different technical structure.
\end{abstract}

\section{Introduction}

Known in economics portfolio diversification one of the most effective methods of reducing investment risk. This concept means the division of the portfolio into different types of investments, among others, in terms of the type of market (e.g. raw materials, currency, shares, bonds), trade (in the case of shares) or geographical coverage of given entities (e.g. shares, shares funds of enterprises from a specific region). In the natural sciences diversification is identified with the biodiversity of fauna and flora in different biosystems [1-4]. Diversification is an important issue in the electricity supply of urban agglomerations [5,6]. Collective water supply system (CWSS) is critical infrastructure which is one of the basic systems for the functioning of urban agglomerations to ensure the security of drinking water supply by public water supply. In the first place CWSS should cover the current and prospective water demand in a technically and economically justified way with respect to natural water resources conservation. Security concise is defined as the ability of a system to protect the interior from external hazards. Analysis and evaluation of both CWSS reliability and security operation indicate the significant role of water resources diversification. Each agglomeration for the proper functioning requires good quality water supply in necessary amount [7]. It is particularly important in crisis or emergency situations. The possibility of water supply from several sources clearly increases the diversification of water supply [8, 9]. If you shut off the water intake or the water intakes the volume of water stored in water supply network tanks plays a key role. An important role is also played by the collective pressure pipelines of the second degree pumping station, whose number and diameter directly affect the reliability of water supply [10-15]. Reducing the water supply or a total lack of water supply can cause threat to water consumers lives or health, as well as financial losses of the recipients and water companies [15-24]. The operator of the CWSS having a high degree of diversification has greater room for manoeuvre in case of crisis, and his decisions do not have to be taken under pressure of time.

The theme of the publication is to present the methodology for determining water supply diversification degree of CWSS. Parameters that have a significant impact on the water supply diversification were proposed:

- number of sub-systems of water supply and their share in the total supply in CWSS,

- number of water tanks and their volume fraction in the whole CWSS,

- number of water mains coming out of the second stage pump with appropriate data rates.

On the basis of these data it is possible to calculate the dimensionless Pielou ratio and assess the degree of diversification of the given collective water supply system, as well as compare even very different water supply systems. The paper presents the calculation of diversification indexes for selected CWSS in Poland.

\section{Methods}

Evelyn Crystal Pielou was an ecologist by education. She significantly contributed to the development of mathematical ecology, mathematical modelling of natural systems. She is the author of six scientific books on this subject [4, 25-30].

From her work on the assessment of the biodiversity degree of biocoenosis, a measure to assess the degree of diversification of water supply to the city was adopted, determined by the formula:

$$
\mathrm{d}_{\mathrm{P}}=\frac{\mathrm{d}_{\mathrm{SW}}}{\mathrm{d}_{\mathrm{SW} \text { max }}}
$$

Corresponding author: kb@prz.edu.pl 
where: $d_{S w}$ is the Shannon-Weaver index, calculated according to:

$$
\mathrm{d}_{\mathrm{SW}}=-\sum_{\mathrm{i}=1}^{\mathrm{n}}\left(\mathrm{u}_{\mathrm{i}} \cdot \ln \mathrm{u}_{\mathrm{i}}\right)
$$

and value $\mathrm{d}_{\mathrm{SWmax}}$ is calculated as:

$$
\mathrm{d}_{\text {SWmax }}=\ln (\mathrm{n})
$$

where:

$u_{i}$ - share of the $\mathrm{i}$-th element in the entirety,

$\mathrm{n}$ - number of elements.

Analysing the formulas (1) and (3) it can be concluded that: for $n=1$ the index $d_{P}$ is undefined, for $n$ $=2$ the index $\mathrm{d}_{\mathrm{P}}=1.0$.

The analysis of the indexes $d_{P}$ shows that:

- with the lack or little unevenness of shares of the index $\mathrm{d}_{\mathrm{P}}$ obtain values near or equal to 1.0 ,

- with the lack of significant balance of shares, the rule that the bigger number of $n$ the higher index $d_{p}$ is not applicable.

It should be noted that for any number $n$, with the same shares the Pielou index obtains the maximum value of an even diversification of 1.0 .

For the assessment of diversification the following parameters were proposed:

$\mathrm{Q}$ - parameter associated with the resource of water in the water supply subsystems (WSS) [31],

$\mathrm{V}$ - parameter associated with the volume of water in the network water tanks $[32,33]$,

M - a parameter related to flow ability of pressure pipelines of the second degree pumping station [15, 24].

Water resources in the individual WSS mean the maximum daily production capacity. The parameter $\mathrm{V}$ includes the volume of the network tanks, i.e. all the tanks located in the technological line after the second stage pumping stations. The study used the specific flowability $\left(\mathrm{m}^{3} / \mathrm{s}\right)$ and taking into account the diameters of pressure pipelines of the second degree pumping station, directly correlated them with the flow. The M parameter takes into account the diameters of the collective pressure pipelines of the second degree pumping station and their roughness. The proposed methodology adopted the same roughness of collective pressure pipelines of the second degree pumping station for the tested systems of public water supply. In further studies it will be possible to take into account the material and age of the pipe (the pipe will have a specific value of roughness).

Diversification degree for parameter Q, V, M were determined according to:

$$
\begin{aligned}
& \mathrm{d}_{\mathrm{Q}}=\frac{-\sum_{\mathrm{i}=1}^{\mathrm{m}}\left(\mathrm{u}_{\mathrm{i}} \cdot \ln \mathrm{u}_{\mathrm{i}}\right)}{\ln \mathrm{m}} \\
& \mathrm{d}_{\mathrm{v}}= \frac{-\sum_{\mathrm{j}=1}^{\mathrm{n}}\left(\mathrm{u}_{\mathrm{j}} \cdot \ln \mathrm{u}_{\mathrm{j}}\right)}{\ln \mathrm{n}} \\
& \mathrm{d}_{\mathrm{M}}=\frac{-\sum_{\mathrm{k}=1}^{\mathrm{p}}\left(\mathrm{u}_{\mathrm{k}} \cdot \ln \mathrm{u}_{\mathrm{k}}\right)}{\ln \mathrm{p}}
\end{aligned}
$$

where: $d_{Q}=$ the diversification index of water resources (intakes) in the CWSS; $\mathrm{d}_{\mathrm{V}}=$ the diversification index of the volume of water in the network water tanks; $d_{M}=$ the diversification index of flowability of collective discharge pipelines of the second stage pumping stations; $\mathrm{u}_{\mathrm{i}}=$ share of maximum daily production capacity of the $\mathrm{i}$-th $\mathrm{CWSS}\left(\mathrm{m}^{3} / \mathrm{d}\right)$ in the total maximum daily capacity of water supply to CWSS; $u_{j}=$ share of the volume of the $\mathrm{j}$-th tank $\left(\mathrm{m}^{3}\right)$ in a total volume of water in the network water tanks; $\mathrm{u}_{\mathrm{k}}=$ share of the flowability of $\mathrm{k}$-th pressure pipelines of the second degree pumping in a sum of flowability of pressure pipelines of the second degree pumping; $\mathrm{m}=$ number of WSS $; \mathrm{n}=$ number of network tanks; $\mathrm{p}=$ number of collective discharge pipelines of the second stage pumping stations.

Global diversification degree was calculated according to:

$$
\mathrm{d}=\mathrm{d}_{\mathrm{Q}}+\mathrm{d}_{\mathrm{V}}+\mathrm{d}_{\mathrm{M}}
$$

In the calculations it was assumed that if $\mathrm{u}_{\mathrm{i}}=1.0, \mathrm{u}_{\mathrm{j}}=$ 1.0 or $\mathrm{u}_{\mathrm{k}}=1.0$, the value of the index $\mathrm{d}_{\mathrm{Q}}, \mathrm{d}_{\mathrm{V}}$ or $\mathrm{d}_{\mathrm{M}}$ taken to calculate the index $\mathrm{d}$ from the equation (7) is 0.0 .

The following standards for the ratio $\mathrm{d}$ were adopted:

$\begin{array}{lll}\text { - } & \text { lack of diversification } & \mathrm{d}=0 \\ \text { - } & \text { low diversification } & 0<\mathrm{d} \leq 1.5 \\ \text { - } & \text { average diversification } & 1.5<\mathrm{d} \leq 2.0 \\ \text { - } & \text { sufficient diversification } & 2.0<\mathrm{d} \leq 2.5 \\ & \text { very satisfactory diversification } & 2.5<\mathrm{d} \leq 3.0\end{array}$

\section{Results and discussion}

Calculations of the assessment of the diversification degree for selected CWSS are presented below.

- Rzeszów

- Q - two intakes:

$\mathrm{u}_{1}=0.43$

$\mathrm{u}_{2}=0.57$

According to (4):

$d_{Q}=\frac{-(0.43 \cdot \ln 0.43+0,57 \cdot \ln 0.57)}{\ln 2}=0.986$

- V - twelve tanks:

$\mathrm{u}_{1}=0.018$

$\mathrm{u}_{2}=\mathrm{u}_{3}=0.054$

$\mathrm{u}_{4}=\mathrm{u}_{5}=\mathrm{u}_{6}=\mathrm{u}_{7}=0.088$

$\mathrm{u}_{8}=0.522$

$\mathrm{u}_{9}=\mathrm{u}_{10}=\mathrm{u}_{11}=\mathrm{u}_{12}=0.02$

According to (5):

$-(0.018 \cdot \ln 0.018+2 \cdot 0.054 \cdot \ln 0.054+4 \cdot 0.088 \cdot \ln 0.088$

$d_{V}=\frac{+0.552 \cdot \ln 0.552+4 \cdot 0.02 \cdot \ln 0.02}{\ln 12}$

- M - four discharge pipelines of the second stage pumping stations:

$\mathrm{u}_{1}=0.03$

$\mathrm{u}_{2}=\mathrm{u}_{3}=0.05$

$\mathrm{u}_{4}=0.87$

According to (6): 
$d_{M}=\frac{-(0.03 \cdot \ln 0.03+2 \cdot 0.05 \cdot \ln 0.05+0.87 \cdot \ln 0.87)}{\ln 4}=0.553$

According to (7):

$d=0,986+0,743+0,553=2,282$

- sufficient diversification

Fig. 1 shows the values of $d_{Q}, d_{V}, d_{M}$ for analyzed CWSS.

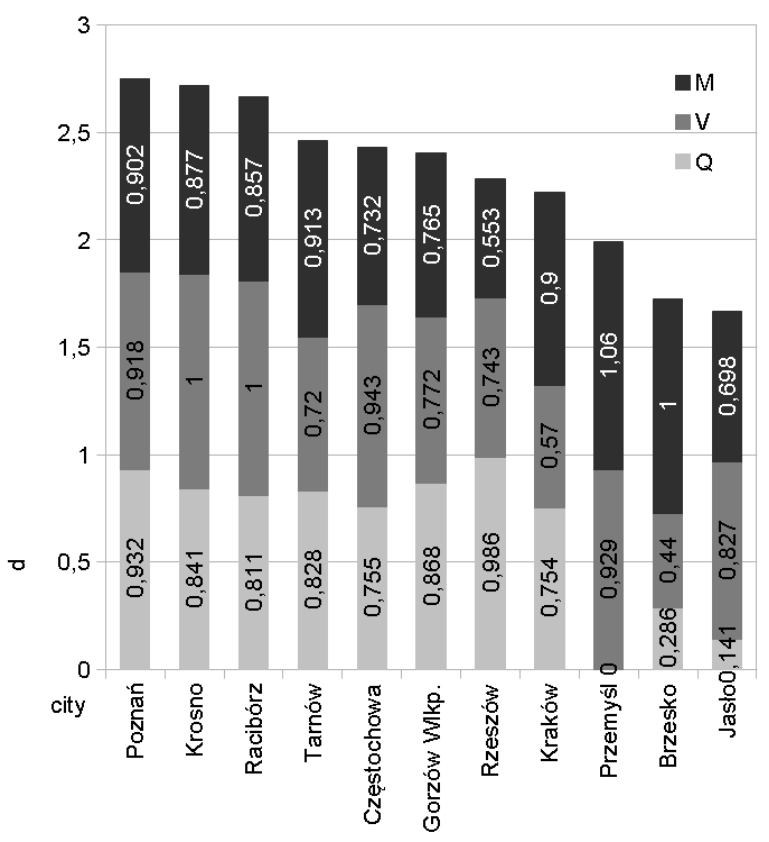

Fig. 1. Values of $d_{Q}, d_{V}, d_{M}$ for analyzed CWSS.

Five out of the analysed CWSS, were classified in the category of sufficient diversification. Highly satisfactory diversification was found for three CWSS, which is due to balanced water resources, volumes and a high value of the index $d_{M}$. As for the proposed in the method three parameters, there are always two of them in the given CWSS, i.e. water intakes and discharge pipelines. In addition, the lack of diversification of water resources in the CWSS Przemysl (one intake, $\mathrm{d}_{\mathrm{Q}}=0$ ) is the cause of the low value of the global index of diversification. With the increase in the number of water intakes, water tanks or collective discharge pipelines of the second stage pumping stations the value of the indexes $\mathrm{d}_{\mathrm{Q}}, \mathrm{d}_{\mathrm{V}}, \mathrm{d}_{\mathrm{M}}$, grows at balanced shares.

\section{Conclusions}

The degree of diversification of water supply in the CWSS is greatly affected by:

- number of the WSS, network tanks, collective discharge pipelines of the second stage pumping stations, evenness of distribution of WSS productivity, volume of network tanks, specific flowability of collective discharge pipelines of the second stage pumping stations, - share of the volume of accumulated water in the size of its collection from the water supply system (the development of criteria and standards is in the process of research).
The CWSS safety is closely related to the diversification of water supply to consumers. It is a desirable situation when during the failure of one of the CWSS elements the recipient of water does not feel any inconvenience related to the operation of the water supply network. The presented method for determining the degree of diversification is a simple tool in the hands of the CWSS operators, showing how the CWSS is prepared to a statutory obligation to supply water.

Dimensionless values of the global diversification index predispose it to analyse the degree of diversification of water supply in different CWSS. They make it possible to compare even very different systems, with one or several intakes, equipped or not equipped with water supply tanks, with different numbers and flowability of collective discharge pipelines of the second stage pumping stations.

The authors are aware that the analyses of the diversification performed in particular cities are result of the technical conditions, the size of water resources in each source, the need for expansion of the CWSS elements. The designers of these systems certainly were not guided by the ability to calculate and assess the degree of diversification because they did not know such concept. We realize that a large number of cities are supplied from a single source (e.g. for Montreal it is a big St. Lawrence river) and the CWSS operate in those cities with satisfactory reliability. The content of the work is a new contribution to the possibility of conscious design of the CWSS expansion, taking into account the diversification as the basis of preliminary reliability.

\section{References}

1. R. Van Velzen, N. Wahlberg, M. Sosef, F. Bakke, Biol. J. Linn. Soc. 108, (2013)

2. M. Hill, Ecology 2 (1973)

3. E. Simpson, Nature 163, (1949)

4. E. C. Pielou, J. Theor. Biol. 13, (1966)

5. R. Muller, M. Steinert, S. Teufel, Energ. Policy 36, (2008)

6. B. Tchórzewska-Cieślak, K. Pietrucha-Urbanik, M. Urbanik, Eksploat. Niezawodn. 18, (2016)

7. W. Kuczyński, W. Żuchowicki, Rocz. Ochr. Sr. 12, (2010)

8. S. Biedgunis, M. Smolarkiewicz, P. Podwójci, A. Czapczuk, Rocz. Ochr. Sr. 9, (2007)

9. M. Dalewska-Kolan, P. Podwójci, Rocz. Ochr. Sr. 11, (2009)

10. J. Bajer, Ecomical and reliability criterion for the optymization of the water supply pumping stations designs. in: Environmental Engineering IV (Taylor \& Francis Group, London, 2013)

11. J. Bajer, Reliability analysis of variant solutions for water pumping stations. in: Environmental Engineering (Taylor \& Francis Group, London, 2007) 
12. B. Tchórzewska-Cieślak, Ochr. Sr. 29 (2007)

13. B. Tchórzewska-Cieślak, D. Szpak, Ochr. Sr. 37 (2015)

14. D. Szpak, B. Tchorzewska-Cieslak, Water producers risk analysis connected with collective water supply system functioning. in: Dependability Engineering and Complex Systems. Advances in Intelligent Systems and Computing, (Springer, Cham 2015)

15. I. Zimoch, Ochr. Sr. 34 (2012) http://www.os.not.pl/docs/czasopismo/2012/42012/Zimoch_4-2012.pdf

16. E. Szymura, I. Zimoch, Przem Chem. 93, (2014)

17. K. Boryczko, A. Tchorzewska-Cieslak, Analysis and assessment of the risk of lack of water supply using the EPANET program in: Environmental Engineering $I V$ (Taylor \& Francis Group, London, 2013)

18. B. Tchórzewska-Cieślak, K. Boryczko, M. Eid, Failure scenarios in water supply system by means of fault tree analysis. in: Advances in Safety, Reliability and Risk Management, (Taylor \& Francis Group, London, 2012)

19. K. Pietrucha-Urbanik, A. Studzinski, Rocz. Ochr. Sr. 18 (2016)

20. B. Kucharski, J. Rak, Environ. Prot. Eng. 35 (2009)

21. B. Tchórzewska-Cieślak, K. Boryczko, I. Piegdoń. Possibilistic risk analysis of failure in water supply network. The European Safety And Reliability Conference (ESREL), (Taylor \& Francis Group, London, 2015)

22. K. Boryczko, I. Piegdoń, M. Eid, Collective water supply systems risk analysis model by means of RENO software. in: Safety, Reliability and Risk Analysis: Beyond the Horizon, (Taylor \& Francis Group, London, 2014)

23. K. Pietrucha-Urbanik, Eng Fail Anal 57, (2015)

24. I. Zimoch, Ochr. Sr. 30 (2008) http://www.os.not.pl/docs/czasopismo/2008/Zimoch 3-2008.pdf

25. E. C. Pielou, The interpretation of ecological data: a primer on classification and ordination (Wiley, New York, 1984)

26. E.C. Pielou, Biogeography (Wiley, New York, 1979)

27. E.C. Pielou, Mathematical ecology (Wiley, New York, 1977)

28. E.C. Pielou, Ecological diversity (Wiley, New York, 1975)

29. E.C. Pielou, Population and community ecology: principles and methods (Gordon and Breach, New York, 1974)

30. E.C. Pielou, Introduction to Mathematical Ecology (Wiley, New York, 1969)

31. J. Rak, A. Włoch, Models of level diversification assessment of Water Supply Subsystems. in:
Underground Infrastructure of Urban Areas 3, (Taylor \& Francis Group, London, 2015)

32. J. Rak, IJCEE 32 (2015)

33. I. Piegdon, B. Tchorzewska-Cieslak, D. Szpak, The use of geographical information system in the analysis of risk of failure of water supply network. in: Environmental Engineering $V$ (Taylor \& Francis Group, London, 2017) 